\title{
OPEN
}

\section{1 \\ Written, Visual and Quantitative Self-Representations}

\begin{abstract}
There are three distinct modes of selfrepresentation in digital media: written, visual and quantitative. Each mode has a separate pre-digital history, each of which is presented briefly in this chapter. Blog and written status updates are descendents of diaries, memoirs, commonplace books and autobiographies. Selfies are descendants of visual artists' self-portraits, and the quantitative modes of lifelogs, personal maps, productivity records and activity trackers are descendants of genres such as accounting, habit tracking and to-do lists. In today's digital culture, the three modes are intertwined. Digital self-representation is conversational and allows new voices to be heard. However, society disciplines digital selfrepresentations such as selfies and blogs through ridicule and pathologising.
\end{abstract}

Rettberg, Jill Walker. Seeing Ourselves Through Technology: How We Use Selfies, Blogs and Wearable Devices to See and Shape Ourselves. Basingstoke: Palgrave Macmillan, 2014. DOI: 10.1057/9781137476661.0003. 
In 1524 Parmigianino painted his Self-Portrait in a Convex Mirror. Parmigianino used oil paints to paint on the hollow inside of half a wooden ball, to mimic the shape of the mirror he copied his reflection from. The distortions of the convex mirror are exactly replicated in Parmigianino's self-portrait. His hand is in the foreground, grossly distorted by the fisheye perspective of the convex mirror he is looking into to see himself. We can just see the short pencil he is holding to sketch his own image. We see what he sees.

Parmigianino used a convex mirror to see himself; today we use digital technologies. We snap selfies on our phones and post them to Instagram. We write about our lives in blogs and in status updates to Facebook. We wear activity trackers on our wrists, log our productivity and allow Facebook and other apps to track our locations continuously. The data we track is displayed back to us as graphs, maps, progress charts and timelines. Parmigianino's self-portrait may not seem to have much in common with a FitBit user's charts of steps and sleep patterns, but both are examples of how technology is a means to see part of ourselves. Whether we use a wearable, networked step-counter or a convex mirror and oil paints, technology can reflect back to us a version of who we are. And the data, filters and social media we use to see and share our reflections distort our images in their own particular ways, just as Parmigianino's convex mirror distorted the perspective of his face.

With digital cameras, smart phones and social media it is easier to create and share our self-representations. But self-representations have always been part of our culture. We have drawn, carved, sculpted and painted images of ourselves for millennia; we have kept diaries, scrapbooks and photo albums; we have sung ballads and told stories about ourselves. Sometimes we use the mediation of technology to help us see ourselves better, to understand ourselves or to improve ourselves, or simply to imagine someone to speak to, a 'dear diary' to tell our secrets to when nobody else will listen. Other times we want to share our experiences with others. We paste photos and memorabilia into a photo album to share with family and imagine one day passing it down to our children and their children. Some of us write autobiographies or memoirs to be published for a wider audience.

This book explores the ways in which we represent ourselves today through digital technologies. Like Parmigianino, we create visual selfportraits and share them. Similar to Augustine and Montaigne, who wrote the first autobiography and the first personal essays, we write 
about our thoughts and our experiences. Like Benjamin Franklin and the farmer keeping a weather diary, we track our habits, locations, to-do lists and other data about our lives.

In this book I aim to show how these strands of self-representation intertwine in digital media in three distinct modes: visual, written and quantitative. In the following chapters, I discuss selfies and photographs as tools for self-improvement and self-knowledge and the power relationships that shift and are contested when new groups of people share their self-representations in the public sphere. In chapter 3 , I propose using the word 'filter' not just to describe Instagram filters or the filtering of the posts we see in our Facebook newsfeeds but also as an analytical term that allows us to understand how certain aspects of our self-expressions are removed or filtered out, and how our self-expression may be altered as we use different technologies, genres and modes to represent ourselves. Chapter 4 discusses the ways in which wearable tracking devices and web services are automating our self-representations and writing our diaries for us. In chapter $5 \mathrm{I}$ look at our new trust in quantitative data, even to express our experiences and emotions. And finally, in chapter 6, I discuss the balance between self-expression and surveillance. Although we take selfies, post updates to Facebook and use a step-counter, others are putting together the data we generate to create their own representations of us.

But first, let us consider the three key modes of self-representation that this book is about: visual, written and quantitative. There are other possible modes. Curation is one, whether we are showing our identity through our record or book collections or by our careful reblogs or retweets on Tumblr or Twitter, or by sharing the music we listen to on Spotify in playlists or as automated Facebook updates. Music, sounds and dance are other modes for self-representation. But for this study I focus on image, text and numbers.

Self-representation online began in text, with images and some sounds being added as graphical browsers were introduced. The visual turn in social media has been particularly strong in the last few years, especially after smart phones with cameras and fast broadband connections for downloading images and video files became increasingly accessible. The quantitative mode of self-representation has also grown vastly in the last few years as wearable devices have made self-tracking easy with consumer devices and as we in parallel have become aware of the extent to which our data is collected and analysed by commercial companies and by governments. 


\section{Writing about the self}

We humans have carved, painted, drawn, sculpted and written about ourselves since we first found ways of making marks in the world. One of the early theorists of the autobiography, Georges Gusdorf (1991), put it thus:

[T] he very first man who set out to speak and write his name inaugurated a new mode of human presence in the world. Beginning with the very first one, any inscription is an inscription of the self, the signature of an individual who tacks himself onto Nature, thus affording himself room to reflect upon and to transmute its meaning. (qtd by Serfaty 2004)

Augustine's Confessions, written in 397-8 CE, is generally recognised as the first autobiography, but writing about oneself was rare until the late sixteenth century. In the Western tradition, diary writing began with spiritual and religious self-examination.

An important reason that people for most of human history only rarely wrote about themselves is the lack of available technology. Paper was expensive, but most importantly, until the last 200 years or so, most people couldn't read and write. In most of Europe, approximately $20-30 \%$ of the population were literate in the early seventeenth century, while $70-90 \%$ could read and write by the end of the nineteenth century (Chartier 2001, 125). This is likely one reason why early autobiographies, such as Augustine's Confessions, were written by priests and nuns, who were more likely than others to have learned to read and write. Almost 1,00o years passed after Augustine's book before autobiographies began to become more common. This may have had to do with social ideas of what was appropriate behaviour as well as to do with literacy and access to pen and paper. In the late sixteenth century, Montaigne noted that drawing yourself was more acceptable than writing about yourself. In one of his many personal essays, he wonders upon seeing the king of Sicily presenting the king of France with a portrait he had drawn of himself, 'why is it not in like manner lawful for everyone to draw himself with a pen, as he did with a crayon?' (Montaigne 1910). His essays, with their digressions and subjective style, were in themselves an important example of the first person becoming prominent in literature.

The first English language autobiography and possibly the first in Europe after Augustine was The Book of Margery Kempe, written by Margery Kempe in 1373. Like Augustine's Confessions, Kempe's book 
told the story of her spiritual life, though her story is, according to Peter Heehs (2013), 'long and somewhat tedious', mostly dealing with her travels in the Holy Land and Italy (31).

By the late eighteenth century the personal diary had become common. Heehs (2013) describes a move from the accounting ledgers necessary for running a business in the renaissance, where people would often add personal notes to their financial accounts, to the 'scores of English Puritans ... keeping their daily accounts with God on paper manuscripts' by the end of the sixteenth century (8). As paper became cheaper and a wider group of people learned to read and write, personal diaries, not necessarily meant for publication, became increasingly common.

It is important to remember that diaries not intended for publication might have still been shared to a greater degree than the private, padlocked diaries that we often think of today when we imagine personal, non-digital diaries. In her study of early blogging, Vivane Serfaty (2004) compares blogs to the diaries of the Puritans, which were, she writes, 'a requirement of religious self-discipline' that 'recounted a spiritual journey towards personal salvation' (5). In this tradition one examines one's own flaws and failures, seeing self-examination as the source for self-improvement and attaining grace. As we see in later chapters, this is much the same stance as we see in productivity apps and the Quantified Self movement.

Heehs argues that the increased availability of books, increased literacy, and not least the growth of Protestantism and its insistence on each Christian's individual relationship with God led to what he calls a 'radical alteration of the way people looked at themselves and the world. Heehs continues: 'It became normal for people to examine their own consciences, and many expressed their thoughts and feelings in memoirs and other first-person genres $(2013,34)$. While Catholics could confess their sins to a priest and be absolved, Protestants were left to their own devices, and so, Heehs argues, many used their diaries as a way of confessing their sins directly to God (49). Heehs quotes a self-help book by John Beadle called A Journal or Diary of a Thankful Christian that was published in 1656 and recommends keeping a journal, because this,

especially if we look often into it, and read it over will be a noteable means to increase in us that self-abasement \& abhorrency of spirit that is most acceptable in the sight of God.... Oh! How will the serious survey of such a Journal 
abase the soul before the Lord! Such a course would very much help our faith. (qtd by Heehs 2013, 51-2)

Although Heehs and Serfaty argue that diary-writing was important to Protestants in particular, writing about the self as a method for selfimprovement was also part of Catholic traditions. For example, the Jesuits had a whole system of spiritual exercises intended to support followers in writing a narrative of their life that allowed them to understand themselves as sinners to become less sinful in the future (Molina 2008). This emphasis on sin is similar to what we saw in Heehs's quote from Beadle's book, and just as Beadle wrote a practical guide to diary-writing, the Jesuits had explicit guidelines for how to write spiritual narratives about oneself. J. Michelle Molina quotes a late sixteenth century description of the Spiritual Exercises that were initiated by St Ignatius, the founder of the Jesuit order:

Consideration of oneself. Tuesday. Points: consideration of self and of time and place: Where are you? Who are you? Also, reflection on each phase of your life: the time, the place, the state of life, circumstances in which he then lived as a sinner in each period; the things he happened to witness, and how swiftly and unmindfully everything passed by. His state of mind then and now. $(2008,289)$

Although Christian traditions of writing about the self emphasised sin there was also room for joy and gratitude. Heehs sets the self-abasement in Beadle's book in contrast to today's self-affirmation (52), but reading through this best-selling seventeenth century guide on how to keep a spiritual journal, which has been digitised and can be read online, we discover that Beadle also writes a great deal about recording mercies, grace and deliverances, not just sin. Here are some of Beadle's notes (1656) about the importance of writing about the good in your life:

To keep a Journal or Diary, especially of God's gracious dealings with us, is a work, for a Christian singularly.... It is good to keep an History, a Register, a Diary, an Annal not only of the places in which we have lived; but of the mercies that have been bellowed on us, continued to us all our dayes.... Remember, and for that end put into your Journal all deliverances from dangers, vouchsafed to you or yours. And indeed, what is our whole life, but a continued deliverance?

A later, secular tradition of personal writing that also has influenced contemporary digital forms of self-expression is the commonplace book. In 1706 John Locke published a book explaining in detail how to organise a commonplace book, with an index to make it easier to relocate quotes and ideas. Ralph Waldo Emerson began to keep such a book, but fused 
it with the personal diary. Lawrence Rosenwald (1988) links this to the specifically American tradition of transcendentalism:

Emerson has chosen to put in his diary not only the continuous record of his life and thought but also the thousand evanescent thoughts by which that record is complicated. In his book, that is, the private and public, the eternal and the contingent, the life and the work will inevitably collide and fuse. Losty speculations must be shown to have arisen in time, in a sequence of other events, from the mind of a particular human being. (59, qtd by Serfaty 2004, 46)

Samuel Pepys' diary is one of the first and certainly best known early secular diaries. He offers as much self-examination as the Puritans, but with less anguish, Heehs writes, citing an example where Pepys in great detail describes a quarrel with his wife without moralising or guilt (6o-1). By the late eighteenth century diaries were common both in everyday life and in fiction, with several novels being written in the form of a diary.

Blogs and online diaries are obvious descendents of the diaries and autobiographies of past centuries. Filterblogs and topic-driven blogs (J.W. Rettberg 2014, 23-7) tend more towards the traditions of the commonplace book or the early Japanese diary tradition of nikki bungaku, which predates the Western diary by several centuries, but in which diaries tell of daily events and barely mention the writer (Heehs 2013, 9). Filter blogs often have a very personal style, much as Montaigne's essays did, but their aim is to share material and ideas that the blogger is interested in rather than to tell the story of the blogger's life. Personal blogs and online diaries are more unequivocally self-representations. The lines between a self-representational blog and one that is not self-representational are not always clear cut. A topic-driven blog (J.W. Rettberg 2014, 23-7) about fashion or the author's research will often mix posts about fashion or research in general with posts showing the blogger's 'outfit of the day' or the researcher's anxieties about finishing her $\mathrm{PhD}$, topics which are clearly self-representational. Anonymous blogs may consist of nothing but captioned reaction gifs, and expose nothing of the author's identity, yet still express a personal experience of life.

\section{Visual self-portraits in history}

Centuries before Parmigianino's Self-Portrait, monks copying manuscripts would often draw small pictures of themselves in their texts, and artists would paint their own face on characters in paintings. In the eighteenth 
century artists' self-portraits became fashionable collectors' items, and towards the end of the twentieth century, artists have increasingly used their own bodies in their art.

Some of the most interesting pre-digital self-portraits in our context are those created by early photographers. Our digital cameras can slip into a pocket or be a lens tacked onto a mobile phone. The first cameras, on the other hand, were huge devices. Just as the camera taking the photograph is visible in digital self-portraits taken in a mirror, so early photographers often included the tool of their trade in their self-portraits. When included, the heavy cameras often appeared as powerful extensions of the photographer's body, as in Kate Matthew's Self-portrait (c. 1900, p 118 in Borzello's Seeing Ourselves [(Borzello, 1998]) or Margaret BourkeWhite's Self-portrait with Camera (c. 1933, p 135 in Borzello). Alternatively, cameras were presented as barriers placed between the photographer and the audience, as in Germaine Krull's Self-portrait with Cigarette and Camera (1925, p 143 in Borzello). Ilse Bing, on the other hand, took self-portraits with a small, compact Leica, including herself, her camera and some of her surroundings and the mirror or other reflective surface she was using to take the photo, in works very reminiscent of today's mirror selfies. In Self-portrait with Leica, 1931 (p 142 in Borzello), Bing holds her small camera a little away from her face, looking just above and past the viewfinder at the spectator, or, as we realise, at herself in the mirror that enables the self-portrait. Another mirror is visible in the left of the picture, offering another view of Bing's face. Her face is serious yet intent, as we usually are when we look at ourselves in the mirror.

Decades later, many self-portraits showed still more fragmented versions of the self, tending to 'conceal or suppress the face and head, thereby thwarting traditional physiognomic/phrenological readings' (Hall 2013, chapter 10, para. 2). Rather than showing a single image of a head and shoulders, or perhaps a whole body, these images may show many fragmentary views (as in Nancy Kitchel's My Face Covered Grandma's Gestures, 1972-73, p 163 in Borzello) or they might show a full body shot again and again, changing a little over time, as in Eleanor Antin's Carving: A Traditional Sculpture (Borzello 1972, 162). As performance art and video art gained territory, self-portraits have become more and more common. Cindy Sherman uses her own image in most if not all of her artwork, posing in different roles. She claims these aren't self-portraits at all, but acting. Sometimes it is hard to draw the line. Perhaps they are a little of both. 
Today's selfies are different in that they are a true vernacular genre. They are rarely exhibited in art galleries; instead they are shared with friends and followers on social media. Although early photographers often used the camera as a barrier to protect them from the viewers in their self-portraits (Borzello 1998, 142), the classic outstretched arm of the selfie taken with a front-facing smart phone camera very strongly includes the viewer in the space of the photograph. As Katie Warwick points out, the outstretched arm is like a (forced) embrace, placing the viewer between the face of the person photographed and the camera (Warfield 2014).

\section{The history of quantitative self-representation}

My six-year-old runs to the window every time she hears a siren and looks for the number written on the side of the ambulance or fire engine. She has set up a siren-watching station with a pencil and paper at the ready by the window, and carefully writes down the numbers in the large, freshly learned script of a kindergartener. Sometimes the numbers are backwards, but she doesn't mind, she can read them. She has organised her log in two sections, one headed with a drawing of a fire engine and one with a drawing of an ambulance. Sometimes she point out patterns in her logs: 'Look, the ambulance with the number 33 on it went that way down the street and then it came back a bit later. But mostly she seems simply to want to keep her logs perfectly up to date. 'I can't miss a siren, Mummy', she explains at bedtime, leaping out of bed to maintain her perfect records.

If the mode of the diary is narrative, then the modes of quantitative self-representation are numbers, lists, maps and graphs. Before today's spreadsheets, activity trackers and GPS diaries, people used pens and paper to track their habits, their money, their sleep patterns and their travels. A prisoner scratching tally marks on the wall for each day of imprisonment is creating a form of quantitative diary, as is the teenager keeping a list of every book she has read or the father noting down the time when he puts his baby down to sleep and the time the baby wakes up.

The ways in which we have represented ourselves with numbers and data have been less studied than the histories of visual self-portraits and written autobiographies, memoirs and diaries, at least from the point of 
view of self-representation and aesthetics. Self-portraits and life-writing, on the other hand, are studied by art historians and literary historians, although unpublished or amateur works have been little discussed until the last few decades.

Benjamin Franklin (2007) was an early self-tracker. In his autobiography he wrote about how he tried to become a better person:

It was about this time I conceiv'd the bold and arduous project of arriving at moral perfection. I wish'd to live without committing any fault at any time; I would conquer all that either natural inclination, custom, or company might lead me into. As I knew, or thought I knew, what was right and wrong, I did not see why I might not always do the one and avoid the other. (63)

Franklin chose 13 virtues he wanted to focus on and drew a chart with a column for each day of the week and a row for each virtue: temperance, silence, order, resolution, frugality, industry, sincerity, justice, moderation, cleanliness, chastity, tranquility and humility. He gave himself a black mark for each day he felt he hadn't lived up to each virtue, and two marks if he had done particularly badly. In the example he shows us in his autobiography we see that he had trouble with silence. He gave himself two black marks for silence on Sunday and one on Monday, Wednesday and Friday. Order was also a problem for him. In the week shown, Franklin was only satisfied with his sense of order on the Wednesday. He did quite well at resolution though, only failing at that on Tuesday and Friday.

This kind of habit tracking was used by many before Franklin and is popular today as well. We use star charts with our children and cross items off our to-do lists with satisfaction.

But self-tracking must have started far earlier than this. The first writing was developed not to record words and sentences but to keep accounts. Arguably, recording quantities of grain or other valuables can be a form of self-representation, or at least representation of what belongs to the self. Medieval annals of history sometimes listed years with no commentary: $726,727,728,729$ and 730 . When words were used to describe a year, the words were brief, as for the year 709 in Annales Sangallenses Maiores, dicti Hepidanni of the Monumenta Germaniae Historica as quoted by Roberto Simanowski: 'Hard winter. Duke Gottfried died.' (2012, 20). Simanowski compares the way the Annales lists years and events without integrating them into a causal narrative with Facebook's automated Timeline (21), which likewise lists events without explanation or causal connections. 
Quantitative self-representation is pre- or post-narrative. Whether we look at Franklin's habit chart or my six-year-old's siren log there is no causal narrative to be seen. We may well infer causality (if the ambulance labelled 33 shows up twice in a row it was probably called out to a medical emergency and then returned to the hospital with the patient) but this requires interpretation. As the literary theorist Wolfgang Iser (1988) argued, we are good at reading more into a story than is written there. We fill in the gaps, what Iser called the lehrstelle, that are not explained in the story. Perhaps as we become more and more accustomed to reading quantitative representations, we will become even more adept a interpreting them as stories.

Literacy and access to writing materials were a pre-requisite for diarywriting. Quantitative self-representations are dependent on other forms of literacy: understanding counting, tables and graphs for instance. For digital forms of quantitative self-representation, we need to understand not only both these basic forms of numeracy and data literacy but also some procedural literacies (Mateas 2005). You don't need to be able to program to use an activity tracker or a lifelogging app, but certainly the most engaging examples of quantitative self-representation are produced by people who know how to access and manipulate their data, and also have the graphic design skills to present it in an appealing and effective way, like Nicholas Felton's annual reports or the examples reported daily at sites like Quantified Self and Flowing Data.

In the last few years, however, we have seen an ever-increasing number of consumer devices that automatically track our activity, posture, health and so on. One in ten adult Americans now owns an activity tracker. Quantitative self-representation is becoming commonplace.

\section{Texts or people?}

Self-representation with digital technologies is also self-documentation. We think not only about how to present ourselves to others, but also log or record moments of our lives for ourselves to remember them in the future. In her ongoing research on selfies, Katie Warfield notes that this is the first time we can use a device to simultaneously see our reflection and record it. Mirrors allowed us to see our own reflection, but not to record it. Cameras allowed us to record our own image, but until the digital display and front-facing camera of the smartphone, they did not allow 
us to see our face as we pressed the shutter (Warfield 2014). That, and the ease and inexpense of deleting digital images and taking new ones, allows us to control the way we are represented to a far greater degree than in a photobooth or holding an analogue camera up to a mirror. Writing a diary is also a way of externalising our thoughts and the way we see or think about ourselves. A private, paper diary may be written for a future self who will look back upon the time of writing. Although wearable devices like Fitbits or apps like Moves or Runkeeper generally suggest we share our steps or runs or productivity in social media, many (perhaps most) users prefer to keep their activity data private, or to only share some of it. When we share photos of our children or a new home or a night out with friends our target audience is not just our friends, but also ourselves.

Social media is about communication with others, but we should be equally aware of how we use social media to reflect upon ourselves. Creating and sharing a selfie is an act of self-representation - which as Gunn Enli and Nancy Thumin (2012) note, means that it involves the creation of texts which will be read and interpreted. A selfie also exists in a social context, once shared. But just as importantly, creating and sharing a selfie or a stream of selfies is a form of self-reflection and selfcreation.

As readers, we encounter other people in social media as texts. From our perspective their self-expression is self-representation. This is particularly true when we are readers more than participants. Until the late 1990s, being on the Internet typically meant communicating with peers, on Usenet discussion forums, IRC, MUDs and MOOs. Early online diarying communities similarly emphasised the community and the social aspects of online diaries. In her study of Internet users' experience of being online, Annette Markham (1998) discusses the relationship between our bodies and the virtual online experience. There weren't many photographs on the Internet in the 1990s. Few people had digital cameras or scanners, and download speeds were so slow that images took a long time to load anyway, so our bodies for the most part were hidden. We imagined that the Internet was disembodied, anonymous and virtual. It wasn't until the late 1990 s and early 2000 s that webcams became popular (Senft 2008), and we began to communicate with each other visually as well as through text. The shift to the visual on the Internet and especially in social media has increased a lot since then. Facebook was originally created to show photos of peoples' faces, and 
today shared images are central to most social media. Our bodies are no longer hidden online.

Images are the primary content of many services such as Instagram, Pinterest, Snapchat and We Heart It. The earlier Internet, on the other hand, relied on words and conversations. People who just watched and read and didn't participate were given the derogatory term lurker, and it was clear that the expectation was active participation. Seeing yourself as a peer communicating with others was key to your identity online, Markham wrote: 'through conversations, self and reality are co-created and sustained' $(1998,227)$. We 'write self into being', but to 'recognize our own existence in any meaningful way, we must be responded to' (Markham 2013a).

When we write and share photos with our friends on Facebook we primarily see the social communication we are engaging in, rather than the text of their and our own self-representations. But when we merely lurk or follow, we position ourselves as traditional readers, as voyeurs, as an audience - and from this point of view, we analyse the other writer primarily as a text rather than as a living, breathing human being. This is the perspective from which selfies and other forms of online selfexpression primarily become self-representations.

Interestingly, some social media sites and apps make it hard to directly communicate with each other, foregrounding the text rather than the conversation or the speakers. We Heart It is an Instagram-like photosharing space that does not allow commenting and only allows users to interact by 'hearting' each other's images. Tumblr doesn't allow direct conversational comments; instead you have to reblog a post on your own Tumblr blog and add notes to it there. This means that only your own followers and not all followers of the original poster will automatically see your notes, and although most Tumblr users write under a pseudonym, it means that anything you write on another user's blog also shows up on your own Tumblr blog.

On the other hand, older forms of online communication such as Usenet discussion groups, MUDs and MOOs or IRC positioned all participants as peers. Each person's words were presented in the same font, in the same manner and made visible to all subscribers, to all players in the same room or to all users in the same channel. Private person-to-person conversation was also possible in many of these earlier communication spaces. For instance, a player in a MUD could whisper something to another character, and other players would only see a 
message such as ' $\mathrm{X}$ whispers something to $\mathrm{Y}$ ' and only $\mathrm{Y}$ would see the content of the message. And of course, in all communication spaces, if users give each other their contact information in another medium (email, telephone, messaging) private communication can be conducted outside of the more public space.

Twitter is an interesting in-between form. On the one hand, every user's posts are presented in exactly the same manner, in a continuous feed that is not dissimilar to the chat interface of a MOO or IRC conversation in the mid-nineties. Using @replies and direct messages people have conversations, and hashtags allow conversations about shared interests to take place between strangers, much as we used to see on Usenet or IRC. On the other hand, every tweet is stored, and you can go back and read all tweets from a particular user in order, as though they are a text. Some users have millions of followers while others have barely any, and it is easy to 'lurk' and read other peoples' tweets without responding to them or in any way making yourself known to the tweeter. It is possible to use Twitter for communication between equals or to be a broadcaster or an audience. In the latter case, a reader - and perhaps also the writer - will see other users' tweets as text, as self-representations rather than as self-expression. The same tweets may be primarily experienced as social communication by other users who engage in conversation with the tweeter, and the tweeter himself or herself may see them primarily as self-exploration and not even really care whether he or she receives any response to them.

An example of the mismatch between seeing a stream of tweets as text rather than as self-expression can be seen in the frequent condemnation of people who tweet or blog or in other ways share stories of illness or hardship in social media. Lisa Boncheck Adams (@AdamsLisa) is a mother of three who tweets and blogs about her life with cancer, in effect writing what G. Thomas Couser (2012) in his categorisation of memoirs would call an autopathography. In mid-January 2014 Adams was undergoing radiation treatment and frequently posted about the pain of side effects, with fairly detailed descriptions of the mundane mechanics of undergoing this kind of treatment:

Pain today is worst in days. Cannot get on top of it. I have 1)constant drip plus ability to do 2)on-demand drip, 3)emergency. All in use. (@AdamsLisa, 8 Jan 2014)

There is more to Adams' Twitter stream than blow by blow descriptions of treatment, though. Many of her posts are humorous, similar to her 16 
December tweet: 'In the Cancer Olympics there would be a medal for contrast chugging \#contender', where the tweet was accompanied by a photo of a jug of red contrast liquid. And each morning she posts the same words as an inspirational call to focus on what is beautiful: 'Find a bit of beauty in the world today. Share it. If you can't find it, create it. Some days this may be hard to do. Persevere.' Importantly, more than half of her tweets are conversational and directly addressed to other users.

Adams came to international media attention after two opinion pieces about the way she tweeted about her illness were published, one by Emma Keller (2014) in The Guardian and one by Bill Keller (2014), Emma's husband, in The New York Times. The two pieces received a great deal of criticism in social media for their judgement of Adams, and Emma Keller's piece was removed from The Guardian a few days later (Elliott 2014).

Emma and Bill Keller explicitly place themselves in the role of traditional audience to Adams' tweets. Instead of participating in the conversation and seeing themselves as Adams' peers or friends, they are readers of a text, members of a large audience watching a performance: 'Her decision to live her cancer onstage invites us to think about it, debate it, learn from it,' Bill Keller (2014) writes, and his use of the term 'onstage' is revealing. He sees Adams primarily as a performer, not as a peer. "Look how swiftly the logic sweeps from "her decision" to "our debates,"' Megan Garber (2014) wrote in The Atlantic. In this way Keller goes from considering Adams as a living person to seeing her (or at least her tweets) as a text to be analysed and criticised from outside just like any other text or performance. Similarly, Emma Keller's piece in The Guardian (since retracted) asked questions from the viewpoint of an audience: 'Should there be boundaries in this kind of experience? Is there such a thing as TMI? Are her tweets a grim equivalent of deathbed selfies, one step further than funeral selfies? Why am I so obsessed?' (E. Keller 2014)

What this approach forgets is that the texts we read in real time in social media represent actual, living people. This is not like writing about a movie or a novel and its fictional characters. It is not even like writing about a movie star or politician, although they of course are also actual, living people. Perhaps Adams could be called a micro-celebrity (Senft 2008, 25-8; Senft 2013), especially after the attention from international news media which led to a rapid increase in followers and readers. But as Alice Marwick (2013) writes, 'the idea of using the tools of celebrity 
culture to analyze the lives of regular people is problematic because the protections available to mainstream celebrities do not exist for microcelebrities.' Micro-celebrities do not have agents and PR consultants to protect them from the press and the public.

In both the Kellers' opinion pieces they criticised Adams for how frequently she tweets. Bill Keller's The New York Times article begins thus,

LISA BONCHEK ADAMS has spent the last seven years in a fierce and very public cage fight with death. Since a mammogram detected the first toxic seeds of cancer in her left breast when she was 37 , she has blogged and tweeted copiously about her contest with the advancing disease. She has tweeted through morphine haze and radiation burn. Even by contemporary standards of social-media self-disclosure, she is a phenomenon. (Last week she tweeted her 165,oooth tweet.)

In the piece, Keller stresses that Adams is 'very public', that she blogs and tweets 'copiously' and is a phenomenon 'even by contemporary standards of social-media disclosure.' The condemnation, almost ridicule, is clear, and one of the reasons she is caricatured in this way is that she speaks too much. 165 , 000 tweets.

Adams herself insists on being read differently. Despite being in hospital when the opinion pieces came out, Adams responded, writing among other things:

My tweet count is not high because I only churn out tweets. It's conversation. Talking.Asking people how they are... And listening for answer. (@AdamsLisa, 14 Jan 2014)

Looking at her Twitter stream it is clear that Adams is right: she places a lot of emphasis on answering tweets from other people and on participating in a conversation. She uses Twitter as a social space for conversation and as a diary, although she certainly also has many followers who don't participate in the conversation.

1305 of the 2402 tweets Adams posted between 15 December 2013 and 15 January 2014 were @replies: they were messages directly addressed to other users. That means that more than half of her tweets were conversational. This is not just Adams talking with a small network of friends. Adams' @replies are addressed to 457 different users, so she participates in a very broad conversation. Her 165 ,00o tweets do not mean she has written an extremely long text, they mean that she is participating daily in conversations with others. 
But of course there is a difference between reading posts from a person we know and care about and reading those of a stranger. And it is natural that Emma and Bill Keller read Adams' tweets with their own response and feelings about the tweets foremost in their minds. We are all at the centre of our own world.

\section{Disciplining self-representations}

The Kellers' condemnation of Lisa Adams is very similar to the disgust that is shown for selfies in the mainstream media. Anne Burns' excellent research blog The Carceral Net: Photography, Feminism and Social Media's Disciplinary Principle (2013-ongoing) documents and analyses many examples of selfie hatred, for instance in 'Selfies and Hatred' (23 May 2014) and 'Selfies and Hatred, Part 2' (30 June 2014).

Some of the hatred is quite direct, such as the t-shirts with the slogan 'Go fuck your \#selfie', or the PBS YouTube video 'Why Do We Hate Selfies?' that normalises the hatred. Other times the disdain for selfies is slightly more subtle, as with the media stories that abounded in April and May 2014 about selfies being a symptom of narcissism, or the idea that selfie-takers need to be helped, for instance made over Pygmalion-style by a benevolent man as in the autumn 2014 ABC TV series 'Selfie'. Anne Burns analyses the trailer for the series in her post 'My Fair Selfie' on 30 May 2014. Ridicule is another approach, and it is for instance seen in the Chainsmokers' video \#SELFIE, which Burns discusses in her 2 May 2014 blog post 'The Curious Confusion of \#Selfie'. Here women are shown in the bathroom having vapid conversations about men and dresses and repeating the chorus, 'First, let me take a selfie.'

Burns sees the hatred, ridicule and pathologising as mechanisms that society uses to discipline the stereotypical selfie-takers: young women. We saw the same mechanism in the early days of blogging. I began blogging in my late twenties as a $\mathrm{PhD}$ student and was often called an exhibitionist or narcissist by non-blogging colleagues (Mortensen and Walker 2002; Walker 2006). I wrote a blog post about this on 24 July 2001, where I accepted the label but asked, 'Why are we so afraid of being thought exhibitionists, anyway?' I quoted Nancy K. Miller's book on personal criticism where she writes about how her mother would deride other women with the condemning words 'She's making a spectacle of herself!' Women have been conditioned not to expose themselves, 
I argued. We've been taught to hide; to be ashamed of 'overly rouged cheeks, of a voice shrill in laughter, or of a sliding bra strap - a loose, dingy bra strap especially' (Miller 1991, 23). Of course, blogging and selfies are not phenomena that are exclusive to women - far from it - but the accusation of blogging or selfies as being narcissistic or exhibitionistic is particularly common when women engage in these practices.

When teenage girls became the most popular and financially successful bloggers in Norway and Sweden towards the end of the first decade of this millennium, they were met by the same disdain as selfies are met with today (Dmitrow-Devold 2013, Palmgren 2010). It is true that the most successful of these blogs were not about the sorts of topics typically seen as valuable by mainstream journalists or arguably by most adults: they were mostly fashion or makeup blogs, full of photos of daily outfits and fashion advice, although the bloggers also sometimes wrote about humanitarian causes or other political issues, and negotiate what Mia Lövheim (2011) calls 'ethical spaces' through their blogging. Today the most successful Norwegian blogs are run by young women and have more daily readers than most Norwegian newspapers. Regardless of the content, it is striking that when young women in their teens and early twenties for the first time have found platforms that allow them to speak without censorship to large public audiences, society's kneejerk reaction is to mock them.

Many scholars, including Anne Burns, have used Michel Foucault's writings about discipline and power to analyse the ways in which mockery, hatred and pathologising are used as disciplinary strategies to put young women in particular back in their place. This is about power and about who has the right to speak in public or to share images in public.

We don't mind so much when celebrities share selfies, as when Ellen DeGeneres shot the famous group selfie of movie stars at the 2014 Oscars. We don't even mind it when people who already have an audience through traditional media tweet about illness and death. When NPR reporter Scott Simon live-tweeted his mother's last days at the end of July 2013, there was a little discussion about whether this was insensitive, or whether it invaded his mother's privacy, or whether Simon could be fully present in the moment with his mother if he was also tweeting. Overall, though, comments were very supportive, and we saw no sustained criticism in major mainstream media. Simon's tweets shared a deep grief, immediately felt: 
You wake up and realize: you weren't dreaming. It happened. Cry like you couldn’t last night. @nprscottsimon 7:14 AM - 30 July 2013

Mother cries Help Me at 2;30. Been holding her like a baby since. She's asleep now. All I can do is hold on to her. (@nprscottsimon 5:35 am, 29 July 2013)

Mother asks, 'Will this go on forever?' She means pain, dread. 'No.' She says, 'But we'll go on forever. You \& me.' Yes. (@nprscottsimon 11:07 PM - 27 July 2013)

Unlike Lisa Adams, Scott Simon was already a well-established journalist with more than a million followers on Twitter. He already had a public persona, so this series of tweets didn't define him.

In 1960, Abbott Joseph Liebling wrote that 'Freedom of the press is guaranteed only to those who own one.' Today you don't need to own a printing press, a newspaper or a television station to share your ideas with the world. Anyone with Internet access can publish whatever they want. But society is finding new ways to regulate who will be heard and who will be taken seriously.

In her article 'Me and My Shadow', Jane Tompkins (1989) asked 'How can we speak personally to one another and not be self-centred?' I think the answer is in the words 'one another'. That is what the Kellers' criticisms of Lisa Adams tweets about cancer miss, and that is what my colleagues missed about my blogging with other $\mathrm{PhD}$ students in my field in the early 20oos, and it is what is missed in the hatred and ridicule of selfies. These aren't simply texts published from a distance. They are images and words that are part of a conversation.

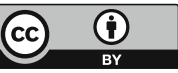

Except where otherwise noted, this work is licensed under a Creative Commons Attribution 3.0 Unported License. To view a copy of this license, visit http://creativecommons.org/licenses/by/3.0/ 